\title{
Bees (Hymenoptera: Apoidea, Apiformes) of the Kujawy Lakeland (central Poland)
}

\author{
Józef BANASZAK and Anna SOBIERAJ-BETLIŃSKA \\ Department of Ecology, Institute of Environmental Biology, Kazimierz Wielki University, 12 Ossolinskich Av., \\ 85-093 Bydgoszcz,Poland; e-mail: lednica@ukw.edu.pl,anna.sobieraj@ukw.edu.pl
}

\begin{abstract}
Bee diversity was studied in 14 habitats in 7 localities in the Kujawy Lakeland (Pojezierze Kujawskie) in central Poland. Additionally, we investigated the species diversity and phenology of bumblebees on red clover (Trifolium pratense). In total, 146 bee species were recorded in the study area, accounting for $30.7 \%$ of bee species reported from Poland so far and $46.2 \%$ of bee species known from the Wielkopolska-Kujawy Lowland (Nizina Wielkopolsko-Kujawska). These include 14 red-listed species.
\end{abstract}

Key words: wild bees, Pojezierze Kujawskie, Nadgoplański Park Tysiąclecia, dominance structure, species occurrence

\section{INTRODUCTION}

Kujawy Lakeland (Pojezierze Kujawskie) is located in central Poland and constitutes the south-eastern part of the Wielkopolska Lakeland (Pojezierze Wielkopolskie). We chose this study area because its bee fauna was not investigated before. Earlier publications included a lot of information on bees in the Wielkopolska-Kujawy Lowland (Nizina WielkopolskoKujawska) (Alfken 1909, 1912, Torka 1913, 1933, Szulczewski 1948, Banaszak 1982, 1983, 1987, Pawlikowski 1989a, 1989b, 1992a, 1992b, 1993), but excluding this mesoregion.

Additionally, we investigated the species diversity and phenology of bumblebees on red clover (Trifolium pratense). Many authors made observations on bumblebees visiting red clover fields in different parts of Poland (Błażejewska et al. 1961, Honczarenko 1965, Ruszkowski \& Biliński 1968, Sowa et al. 1974, 1983, 1991a, 1991b, Anasiewicz 1976, Biliński 1977, Kosior 1980, Banaszak 1984, Biliński \& Ruszkowski 1991).

\section{MATERIAL AND METHODS}

\section{Study area}

According to the physico-geographical division of Poland (Kondracki 2009), the Kujawy Lakeland (mesoregion 315.57) constitutes the south-eastern part of the Wielkopolska Lakeland (macroregion 315). This is an agricultural mesoregion with fertile soils and a small percentage contribution of forests. It covers an area of $2500 \mathrm{~km}^{2}$ and includes the "Nadgoplański Park Tysiąclecia" Landscape Park, which is of high conservation value. The Landscape Park includes Natura 2000 sites: Special Protection Area PLB040004 “Ostoja Nadgoplańska”, and Special Area of Conservation PLH40007 Lake Gopło. In historical and ethnographic terms, the study area is part of the Kujawy region, situated between the upper Noteć River, Lake Gopło, and the Vistula (Mileska 1994). According to the climatic regionalization of Woś (1999), the Kujawy Lakeland is located in region XV, i.e. the central-Wielkopolska region (the largest one in Poland). It is characterized by a high frequency of days with very warm and cloudy weather, and often ground frost on very cold days with precipitation (Woś 2003). 


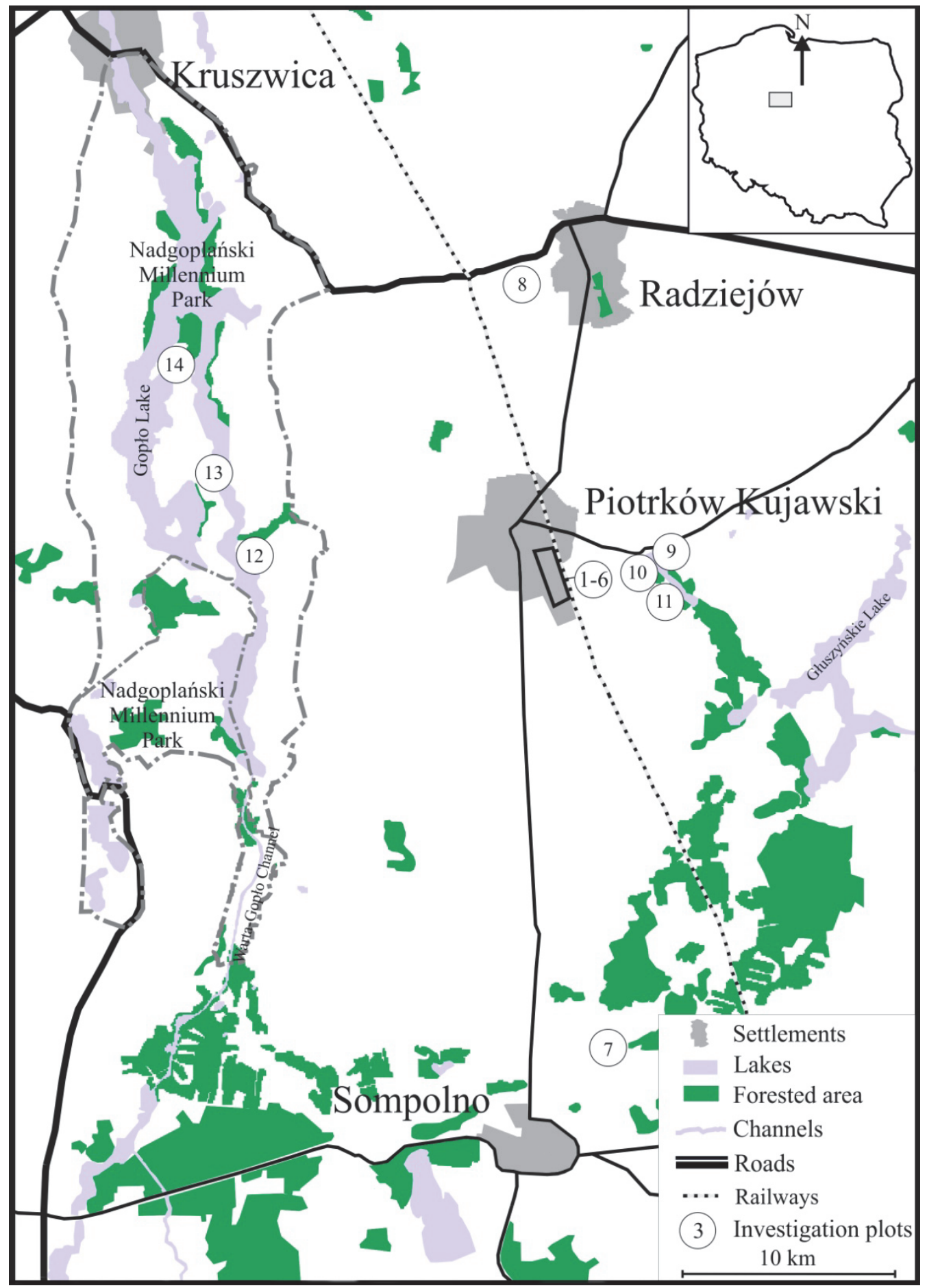

Fig. 1. Map of the investigated area of the Kujawy Lakeland, with location of study sites (description in the main body of the article). 


\section{Description of research plots}

Material was collected from 14 habitats in 7 localities (Fig. 1). Most of the plots were designated in the town of Piotrków Kujawski (UTM: CD32, plots 1-6). Within the "Nadgoplański Park Tysiąclecia" Landscape Park, 3 plots were investigated: xerothermic grassland on the eastern edge of Lake Gopło in the village of Mietlica (UTM: CD22) as well as moderately moist meadow (UTM: CD22) and old field (UTM: CD23) on the Potrzymiech peninsula in the village of Ostrówek. Additionally, the old field is even more strongly protected as part of the nature reserve "Nadgoplański Park Tysiąclecia" (Zarządzenie 2015). The Regional Director of Environmental Protection in Bydgoszcz agreed to insect collection in the reserve in this study (permission number WPN.6205.64.2015.KLD). The other investigated habitats were: a manor park and forest community in the village of Świesz (UTM: CD32), forest glade in the village of Lubsin (UTM: CD32), willow thicket in the village of Synogać (UTM: CD31), and winter oilseed rape field in the village of Czołowo (UTM: CD33).

According to the latest geobotanical classification of Poland, the investigated localities are within the Brandenburg-Wielkopolska Division (Matuszkiewicz 2008a). The dominant type of potential natural vegetation in the analysed area of the Kujawy Lakeland is Central European oak-hornbeam forest Galio-Carpinetum (variant characteristic of Kujawy), in both its poor and fertile series. Other types of potential natural vegetation in the study area are lowland ash-alder forest Fraxino-Alnetum and lowland elm-oak forest Ficario-Ulmetum chrysosplenietosum (Matuszkiewicz 2008b).

Detailed characteristics of research plots are presented below.

1. Synanthropic site composed of a neglected 40-year-old orchard, flower beds, and vegetable garden. Bee forage plants include many trees: cultivated varieties of Malus domestica (Reneta, Papierówka, and Kosztela), and Prunus domestica (ssp. syriaca, ssp. insititia, ssp. italica var. claudiana), P. cerasus, P. persica, Pyrus communis, and Crataegus monogyna. Shrubs are represented by single specimens of Rosa canina and Syringa vulgaris. Herbaceous bee forage plants include Taraxacum officinale, Malva pusilla, Alcea rosea, Helianthus annuus, Calendula officinalis, and cultivated species of Cucurbitaceae, Solanaceae and Fabaceae. Herbaceous vegetation was grazed by cattle. The plot included also a clay wall of a farm building, where nests of several species of wild bees were observed. Bees were studied there in April-May in 2011 and 2012, and in April-September in 2013 and 2014.

2a. Sandy grassland community of the alliance Koelerion glaucae, developed on an old field abandoned about 25 years ago. It is subject to ecological succession towards forest communities: gradually colonized by woody plants, e.g. Robinia pseudoacacia, Pinus sylvestris (large patches), and Betula pendula. The habitat directly borders with a yellow lupine field, hay meadows, and farm buildings. It is a dry and sandy site, so the major plant species are Centaurea stoebe, C. scabiosa, Echium vulgare, Oenothera biennis, Jasione montana, Helichrysum arenarium, and Berteroa incana, accompanied by less numerous Taraxacum officinale, Achillea millefolium, Senecio jacobea, Verbascum thapsus, and Vicia sp. Bees were studied there in June-August in 2013 and 2014.

2b. Sandy grassland community of the alliance Koelerion gaucae. The overgrown earth dump reaches $111.7 \mathrm{~m}$ a.s.l. At this site, a cholera cemetery was located, and human bones were exposed during construction of a housing estate, so they were next deposited at the nearby parish cemetery (Kowalski 2009). The scarp is anthropogenic, as sand is extracted there by local inhabitants. The site directly borders with an industrial plant, cemetery, housing estate, and wheat field. Currently secondary succession at this site is advanced, which is evidenced by the presence of trees, e.g. Quercus robur, Robinia pseudoacacia, and Betula pendula, as well as numerous shrubs: Syringa vulgaris, Prunus persica, Acer negundo, and Juglans regia. 
Herbaceous bee forage plants are represented by Anchusa officinalis, Berteroa incana, Carduus crispus, Centaurea scabiosa, Consolida regalis, Echium vulgare, Hypericum perforatum, Knautia arvensis, Silene vulgaris, and Veronica spicata. Bees were studied there in June-August in 2013 and 2014.

3. Roadside, mostly with ruderal plant communities of the orders Onopordetalia acanthii and Artemisietalia vulgaris. It extends along a railway embankment on one side, while on the other side it borders with arable fields, houses, and industrial buildings. Field research was carried out on both sides of the road, along its section about $1 \mathrm{~km}$ long. Herbaceous vegetation was numerously represented by Berteroa incana, Cichorium intybus, Cirsium arvense, Echium vulgare, Epilobium hirsutum, Eryngium planum, Lamium purpureum, Lathyrus pratensis, Linaria vulgaris, Melilotus alba, Medicago sativa, Onopordum acanthium, Potentilla reptans, Sedum acre, Tanacetum vulgare, Trifolium pratense, and Vicia cracca. The only shrubs were Prunus domestica ssp. syriaca, Rosa rugosa, and Salix fragilis, and the only tree species was Tilia cordata (several specimens). Bees were studied in April-September in 2013 and 2014.

4. Hay meadow/pasture, neighbouring with an also investigated meadow (dominated by Molinia caerulea) and a thick belt of emergent vegetation. This species-poor permanent grassland includes few bee forage plants: Taraxacum officinale, Trifolium repens, and Leontodon autumnalis, with single clumps of Trifolium pratense and Ononis arvensis. At the edges of the meadow, some shrubs are found: Salix caprea and S. fragilis. Bees were studied there in April-May in 2011 and 2012, and in April-September in 2013.

5. Periodically waterlogged meadow (dominated by the grass Molinia caerulea) of the order Molinietalia caeruleae. Unexploited for 8 years. Adjacent to a drainage ditch lined with trees: Alnus glutinosa, Salix alba, and Prunus cerasifera. Common wetland plant species are found there: Epilobium hirsutum, Lythrum salicaria, Lysimachia vulgaris, Inula britannica, Potentilla anserina, Mentha arvensis, and Acorus calamus. Tall herbs Lysimachia vulgaris and Lythrum salicaria attest to the first stage of ecological succession in the meadow. Other numerously represented species were: Centaurea jacea, Vicia cracca, Lathyrus pratensis, Cirsium arvense, Arctium tomentosum, Rhinanthus serotinus, and Pastinaca sativa. Bees were studied in April-September in 2013 and 2014.

6a. Red clover field. Surrounded by the hay meadow/pasture, which was also investigated. Clover was harvested twice a year. Additionally, in 2011, cattle grazed there sporadically. The plantation was mixed with white clover Trifolium repens (which covered about $20 \%$ of the area) and single specimens of Achillea millefolium. Bees were studied there in AprilSeptember in 2011 and 2012, and in May-August in 2013.

6b. Red clover field. Harvested twice a year. Bee forage plants represented also by Taraxacum officinale, Achillea millefolium, and Vicia cracca. Bees were studied there in April-September in 2011 and 2012, and in May-August in 2013.

7. Willow thicket forming a belt along a drainage ditch. Tree layer mostly composed of Salix alba, S. caprea, and Betula pendula. Shrub layer consisting of the same Salix species. Surrounded by hay meadows and pastures, dominated by grasses. Bees were studied there in April 2013.

8. Winter oilseed rape Brassica napus var. napus. Neighbouring with a wheat field, farm buildings, houses, and a road. Bees were studied there in May 2013.

9. Historical manor park, dating back from the 18th and 19th centuries. Located at the eastern edge of the small Lake Świesz. Only the immediate vicinity of the manor house is managed. The park includes 3 lines of Tilia cordata, composed of nearly 50 trees. Other tree species include Carpinus betulus, Aesculus hippocastanum, Fraxinus excelsior, Larix decidua, and Picea abies. The lower layer of vegetation is dominated by ruderal herbs: Leonurus cardiaca, Chelidonium majus, and Anchusa officinalis. Bees were studied there in AprilAugust 2014. 
10. Forest, on a potential site of moderately moist, mixed coniferous forest. Not adjacent to Lake Świesz. Tree layer dominated by 40 -year-old Pinus sylvestris, and locally Robinia pseudoacacia and Betula pendula. Shrub layer consisting of Sambucus nigra, Frangula alnus, Robinia pseudoacacia, and Rubus sp. Forest edge with abundant Chelidonium majus. Bees were studied there in May-June 2014.

11. Forest glade south of Lake Świesz, it borders with a pool separated by a narrow levee from a fish pond. Numerous shrubs: Sambucus nigra and Prunus padus. Grasses tall and lush, with small contributions of Lamium purpureum, Leontodon hispidus, and Knautia arvensis. Bees were studied there in April-August 2014.

12. Xerothermic grassland of the class Festuco-Brometea (alliance Asplenion septentrionalis-Festucion pallentis), covering an elevated earth bank, which is a remnant of a Goplan stronghold built in the late $9^{\text {th }}$ century and early $10^{\text {th }}$ century (Dzieduszycka 1985). Many thermophilous plant species, e.g. Anchusa officinalis, Asparagus officinalis, Centaurea rhenana, Lavatera thuringiaca, Dianthus carthusianorum, Phleum phleoides, Potentilla arenaria, Salvia pratensis, Securigera varia, Stachys recta, Silene otites, Thalictrum minus, and Veronica spicata. Accompanied by ruderal species, such as Anthriscus cerefolium and Onopordon acanthium. This habitat is threatened by a spreading oak forest stand, which shades the slope, leading to decline of the valuable thermophilous vegetation. Bees were studied there in April-August 2015.

13. Moderately moist hay meadow of the alliance Arrhenatherion elatioris. Characterized by large patches of abundantly flowering Centaurea jacea in summer. Bees were studied there in July-August 2015.

14. Old field bordered with a reed belt, farmland, and alluvial oak-elm-ash forest FicarioUlmetum. Major bee forage plants: Vicia cracca and Brassica napus. Bees were studied there in July-August 2015.

\section{Research methods}

Faunistic material was collected by catching of noticed bees with an insect net directly on bee forage plants, during flight or at their nesting sites. Bees were caught for $1 \mathrm{~h}$ during observations made in favourable conditions for their activity, i.e. between 9 am and $5 \mathrm{pm}$, at temperatures ranging from $15^{\circ} \mathrm{C}$ to $32^{\circ} \mathrm{C}$, with no or very little wind. The field research was conducted in 5 growing seasons, in 2011-2015. The collected material was prepared, identified to species, and deposited in the collection of the Department of Ecology, Institute of Environmental Biology, Kazimierz Wielki University, Bydgoszcz, except for protected species, which were identified alive in the field and next released. During the counting and catching of bees, also the plant species visited by them were recorded. Honey bees were observed at all the analysed sites, but this species was not taken into account because of its anthropogenic origin.

When analysing the material, to describe various levels of dominance index, we distinguished 5 classes according to Kasprzak \& Niedbała (1981): eudominants $\left(\mathrm{D}_{5}\right)$, i.e. species accounting for $>10.0 \%$ of the total catch; dominants $\left(\mathrm{D}_{4}\right)-$ from 5.1 to $10.0 \%$; subdominants $\left(\mathrm{D}_{3}\right)$ - from 2.1 to $5.0 \%$; recedents $\left(\mathrm{D}_{2}\right)$ - from 1.1 to $2.0 \%$; and subrecedents $\left(\mathrm{D}_{1}\right) \leq 1.0 \%$.

To analyse species richness, a rarefaction curve was constructed (according to Gotelli \& Colwell 2001). Additionally, the Shannon index $\left(H^{\prime}\right)$ of species diversity was calculated (Magurran 2004):

$$
H^{\prime}=-\sum_{i=1}^{S} p_{i} \ln \left(p_{i}\right)
$$


where $p_{i}$ is the proportion of individuals belonging to the $i$ th species in the community of $S$ recorded species.

To estimate the total number of species (the so-called complete species richness), we used the chao2 method (Chao 1987). It is a classic estimator based on single and double observations of occurrence of individual species in the samples. The calculations were made using EstimateS v. 9.1 software (Colwell 2013).

Species names and categories of threat follow those used in the "Fauna of Poland" (Banaszak 2004).

Most of the habitats are described in general, on the basis of own observations in the field (AS-B). Only the description of the plant cover in Mietlica and Ostrówek is based on the literature (Zarządzenie 2015). For each site, we determined its location on the UTM $1 \mathrm{~km} \times 1$ km grid by means of Gnomon version 3.3 software (Desmodus, Poland).

\section{RESULTS}

\section{Species diversity and dominance structure of wild bees of the Kujawy Lakeland}

In total, 6312 wild bees were caught and observed. All species and numbers of specimens recorded at individual research sites are listed in Table 1.

The list of recorded bee species in the Kujawy Lakeland is incomplete, as the mean species accumulation curve (Fig. 2) for the total of 6312 recorded individuals still shows an increasing trend. The expected number of species calculated on the basis of the chao2 estimator was 190 (95\% CI $=166-242)$. The percentage contribution of caught species to the total estimated number $(76.8 \%)$ indicates that the collected material is representative, as it is based on observation of at least $70 \%$ of species possible to detect (Williams et al. 2001). The high Shannon index (3.5) attests to a high bee species diversity in the study area.

In the community of caught and observed bees of the Kujawy Lakeland, the only eudominant was Bombus terrestris (14.6\%). Dominants (33.7\% in total) included Andrena vaga $(8.4 \%)$, B. lapidarius (7.4\%), A. haemorrhoa (6.5\%), B. pascuorum (6.0\%), and Osmia rufa (5.4\%) (Fig. 3). All the species are common in Poland. Subdominants in total accounted for $24.5 \%$, recedents for $8.4 \%$, and subrecendents for $18.9 \%$. The remaining 55 species $(37.7 \%)$ were represented by $1-3$ individuals.

The total numbers of wild bee species in individual habitats were as follows: 70 on xerothermic grassland, 64 on the synanthropic site, 56 on sandy grassland 'a', 54 on the roadside, 40 on hay meadow/pasture, 38 in the forest glade, 35 on the periodically waterlogged meadow, 29 in willow thickets, 26 on sandy grassland b, 19 on the moderately moist meadow, 17 on red clover ' $a$ ', 14 on red clover field ' $b$ ', 14 in the historical manor park, 11 in the old field, 11 in the rape field, and 6 in the forest (Fig. 4).

\section{Overview of noteworthy species}

Among the recorded species, 9 are vulnerable (VU): Andrena alfkenella, A. falsifica, A. nasuta, A. nycthemera, A. potentillae, A. suerinensis, Anthocopa bidentata, A. papaveris, and Nomada opaca. Besides, a species of least concern (LC) was noted, i.e. Nomada moeschleri, and 4 species classified as data deficient (DD): Hylaeus leptocephalus, $H$. gracilicornis, $H$. gredleri, and Epeoloides coecutiens (Banaszak 2004). Many more species of bees appeared on the European Red List of Bees (Nieto et al. 2014). Particularly noteworthy species are briefly presented below. 


\section{Hylaeus gredleri Förster}

A southern species, in Poland till the end of the 20th century found only in the KrakówCzęstochowa Upland (Celary 1999) and in the Bieszczady Mts (Celary \& Wiśniowski 2001), but recently observed also in other parts of the country (Banaszak \& Kowalczyk 2007, Banaszak 2006, 2010a, 2010b, Banaszak \& Jaroszewicz 2009, Banaszak \& Twerd 2015). New record: Piotrków Kujawski, roadside 05 Jul 2013, 1 q, 1 §๋.

\section{Andrena alfkenella Perkins}

Rare in Poland, nesting in the ground. New record: Ostrówek, moderately moist meadow, 15 Aug 2015, 2 우.

\section{Andrena falsifica Perkins}

Rare in Poland, nesting singly in the ground. New record: Mietlica, xerothermic grassland, 19 Apr 2015, 10 우, 2 ô่ $\hat{o}^{\prime} ; 23$ May 2015, 1 ㅇ.

\section{Andrena nasuta Giraud}

Rare in Poland. New record: Mietlica, xerothermic grassland, 20 Jun 2015, 3 우.

\section{Andrena nycthemera Imhoff}

In Poland known from few, isolated localities. Forms small colonies on sandy elevations (Dylewska 2000). New record: Mietlica, xerothermic grassland, 19 Apr 2015, 2 우.

\section{Andrena potentillae Panzer}

Nesting singly on dry sites. New record: Mietlica, xerothermic grassland, 19 Apr 2015, 1 ○.

\section{Andrena suerinensis Friese}

In Poland known from scattered localities in all parts of Poland. Nests in the ground, in small colonies on steppe slopes (Dylewska 2000). New record: Mietlica, xerothermic

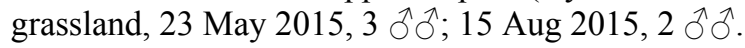

\section{Epeoloides coecutiens (Fabricius)}

Cleptoparasite of Macropis fulvipes (Straka \& Bogusz 2007). New record: Piotrków

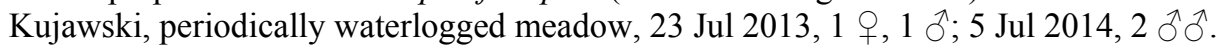

\section{Nomada opaca Alfken}

Rare in Poland, but reported from many parts of the country. New record: Piotrków Kujawski, synanthropic site, 10 May 2013, 1 क; 02 May 2014, 4 o+ +19 Apr 2014, 1 ऽ.

\section{Bombus jonellus (Kirby)}

Usually classified as an Boreal-Alpine species, in Poland frequently recorded also at cold and moist sites. New record: Świesz, forest, 28 Jun 2014, 1 \%.

\section{Bombus soroeensis soroeensis (Fabricius)}

Very rare subspecies in Poland, which is its western limit and the eastern limit of more abundant subspecies B. s. proteus. Associated with forest habitats. New record: Lubsin, forest glade, 30 Aug 2014, 1 웅 Świesz, forest, 28 Jul 2014, 1 ‥ 


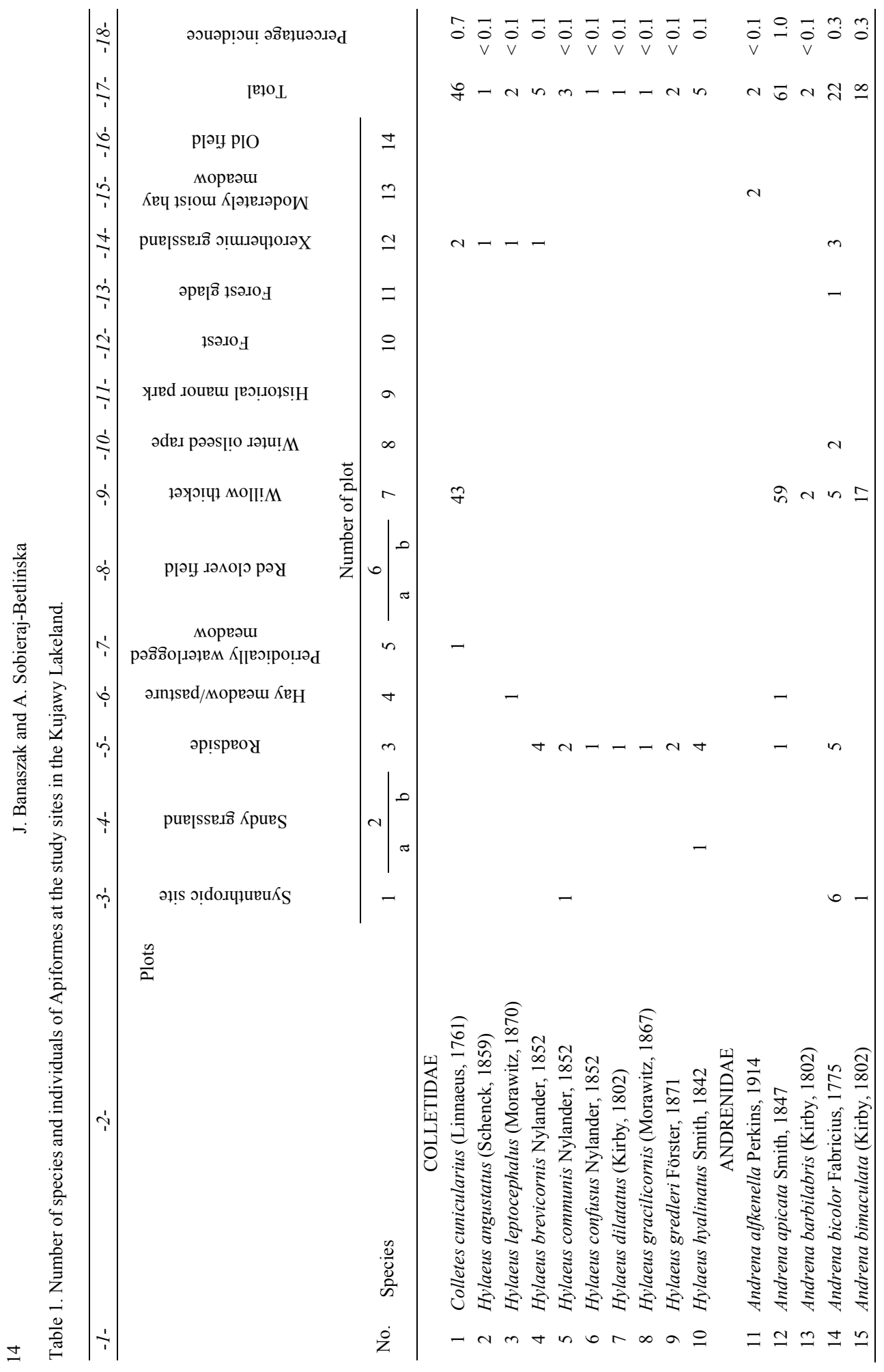




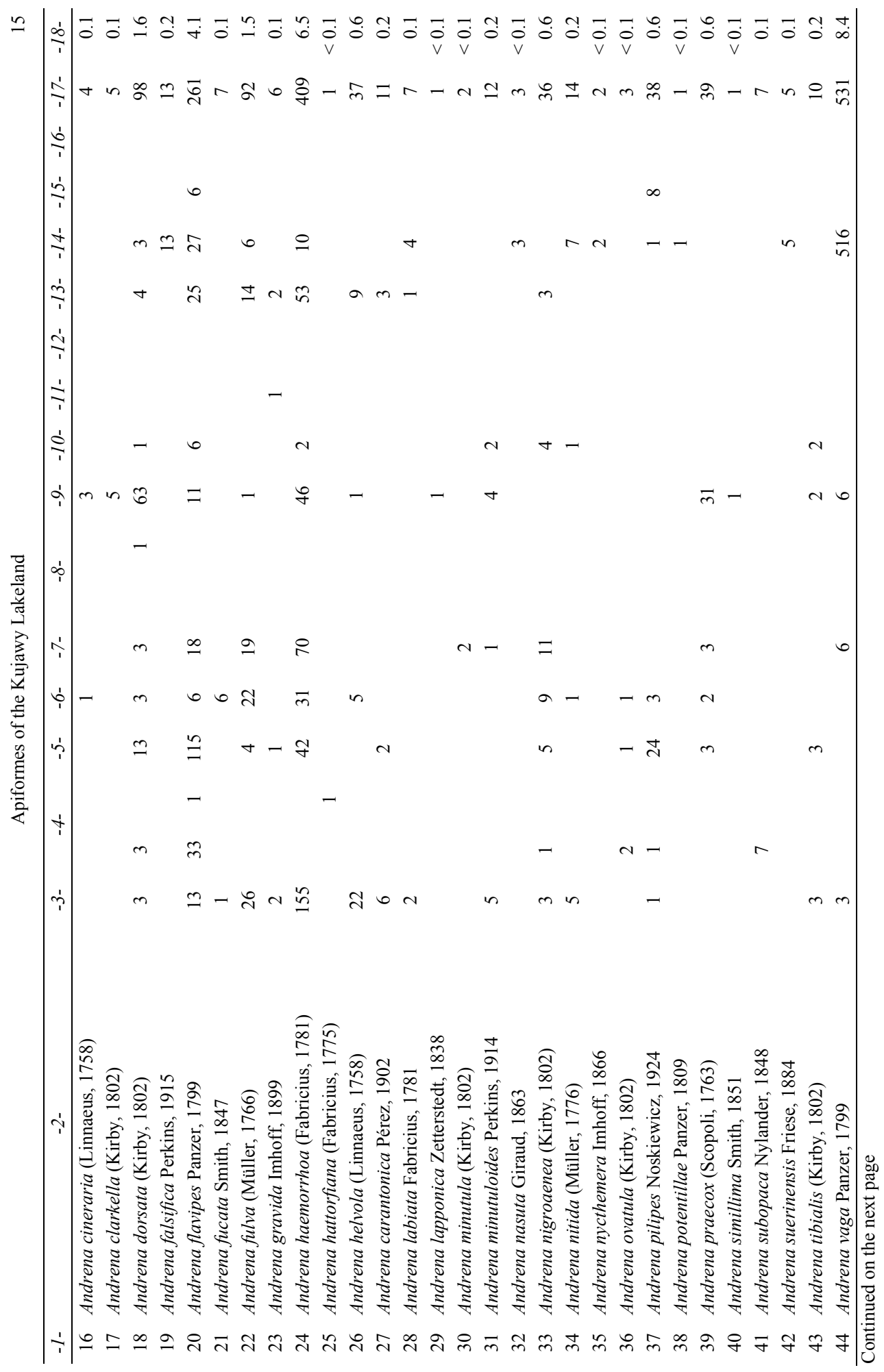









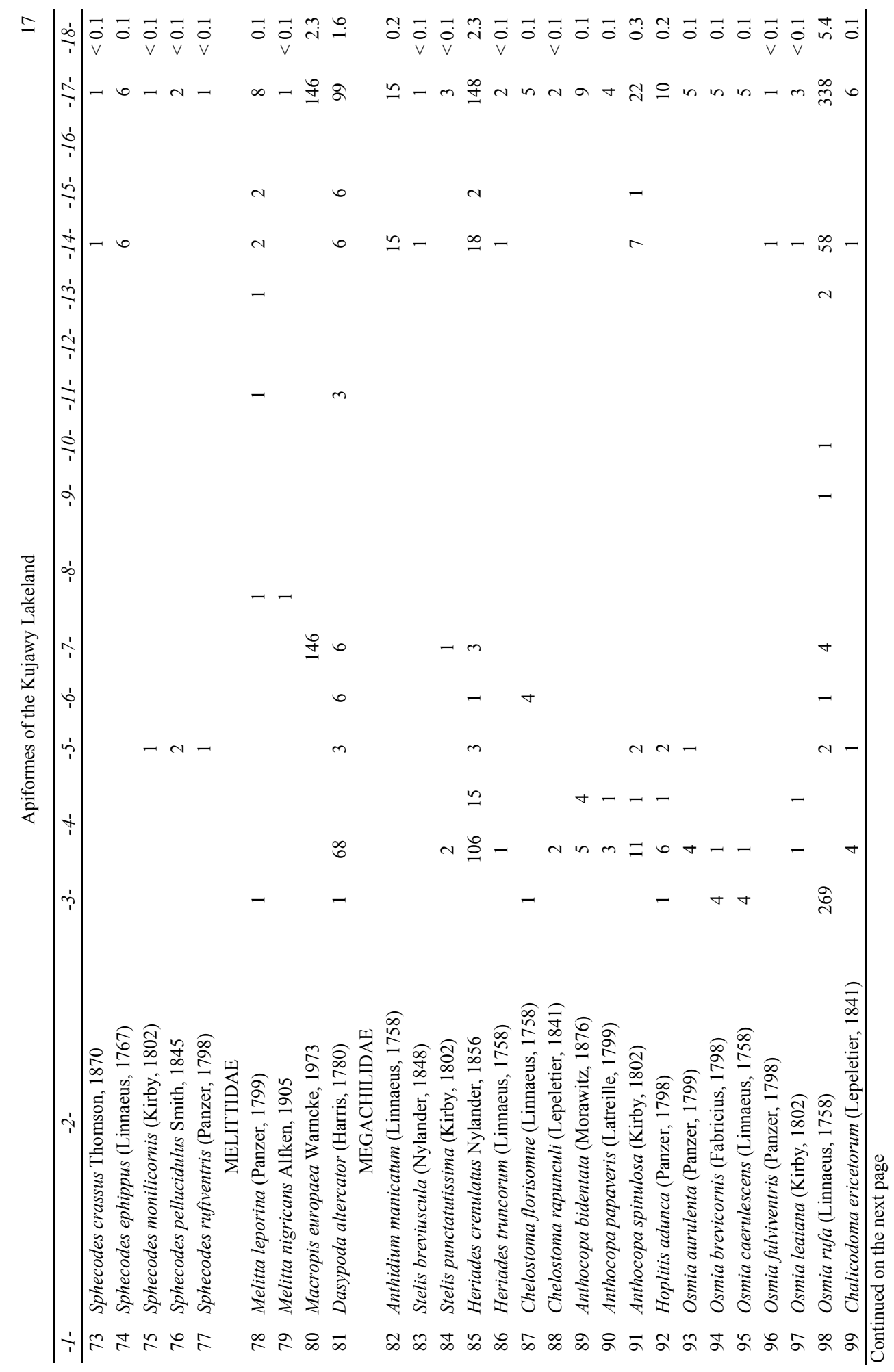




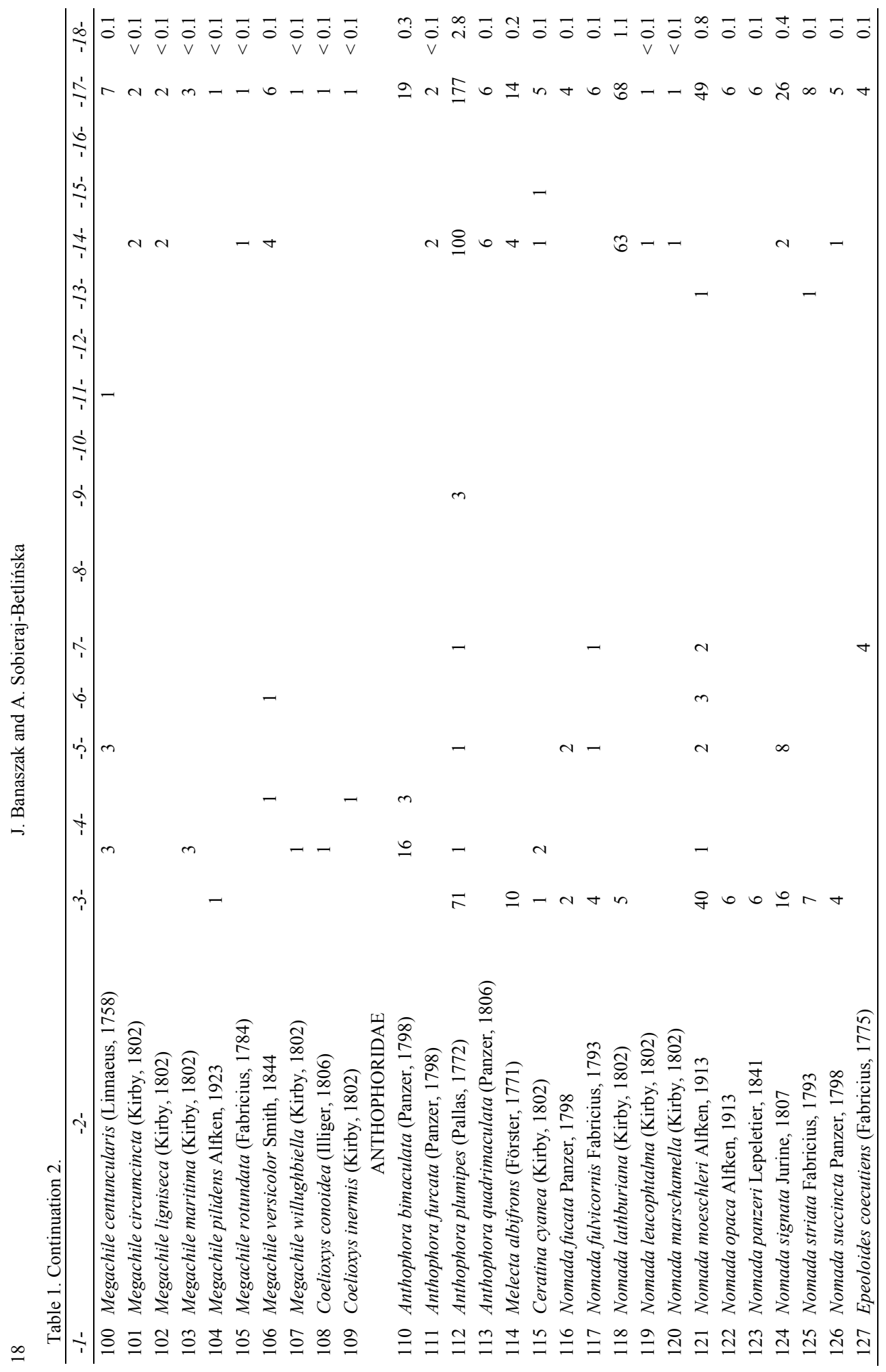




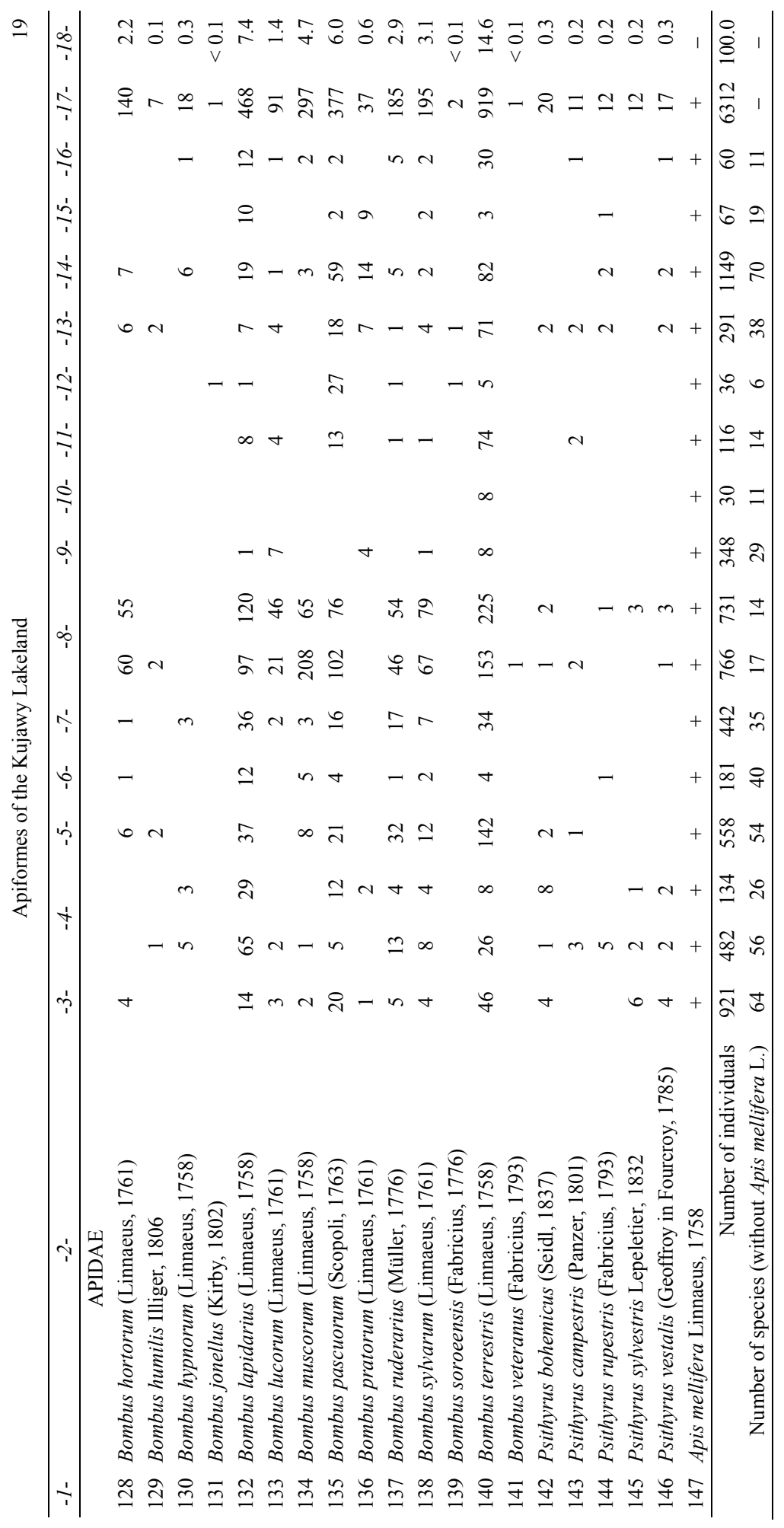




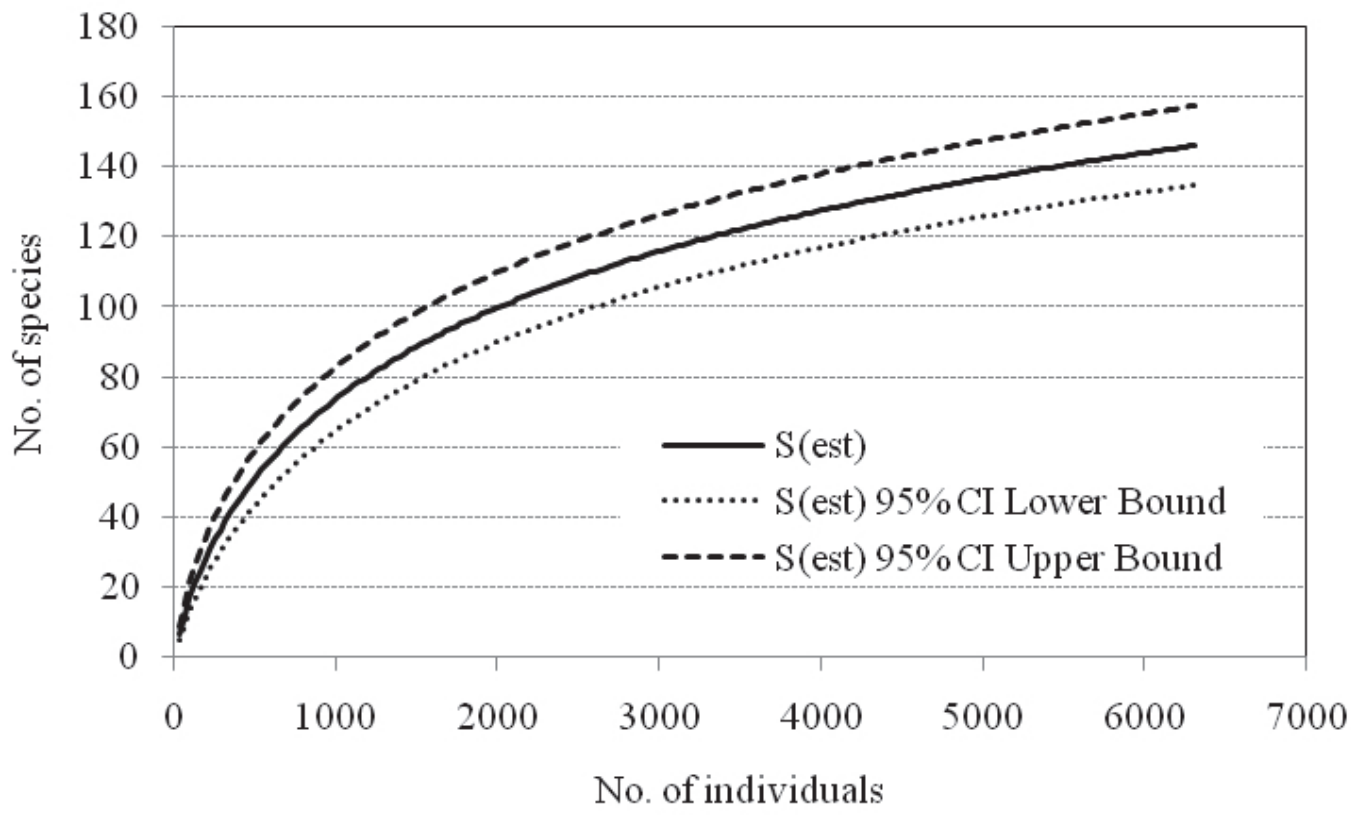

Fig. 2. Expected species richness based on the rarefaction curve for the Kujawy Lakeland. Confidence intervals are marked with a broken line.

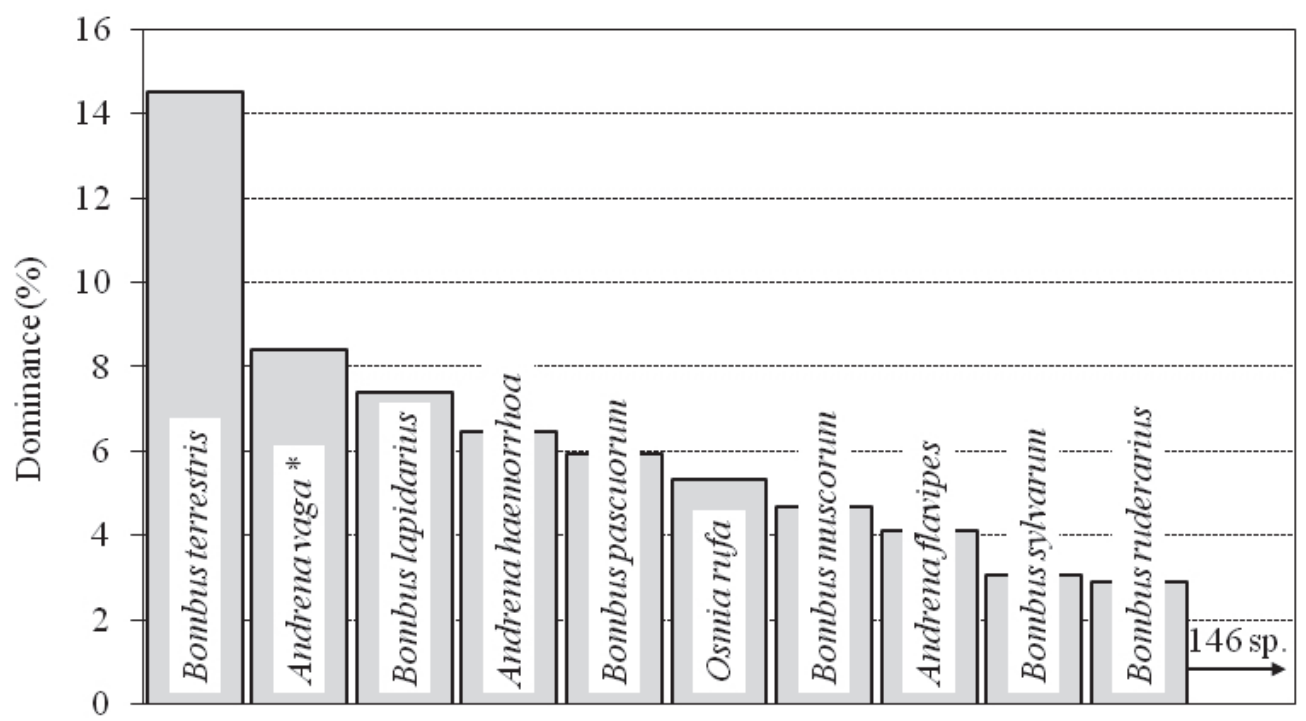

Fig. 3. Dominance structure of wild bees in the Kujawy Lakeland in 2011-2015. The most abundant species, represented by a given number of caught individuals, are marked with asterisks. 


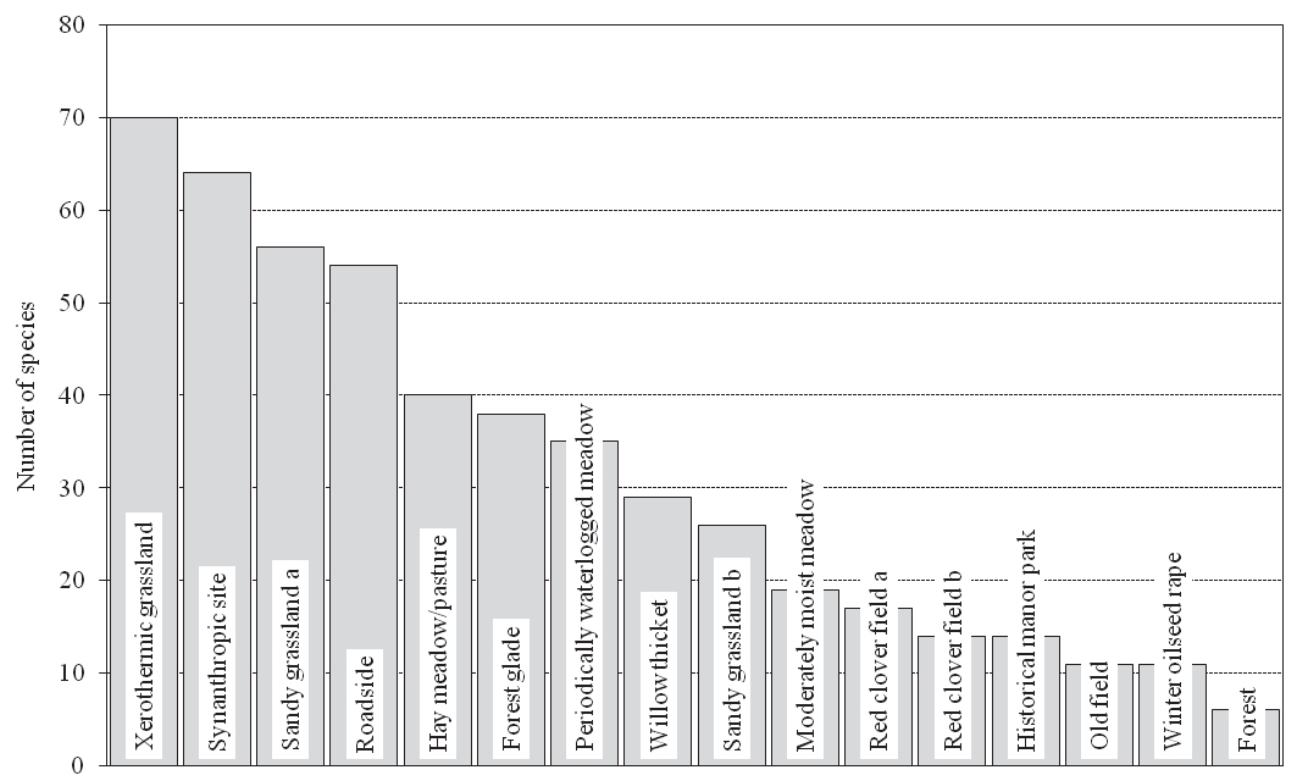

Fig. 4. Number of species of Apiformes at the particular study sites in the Kujawy Lakeland.

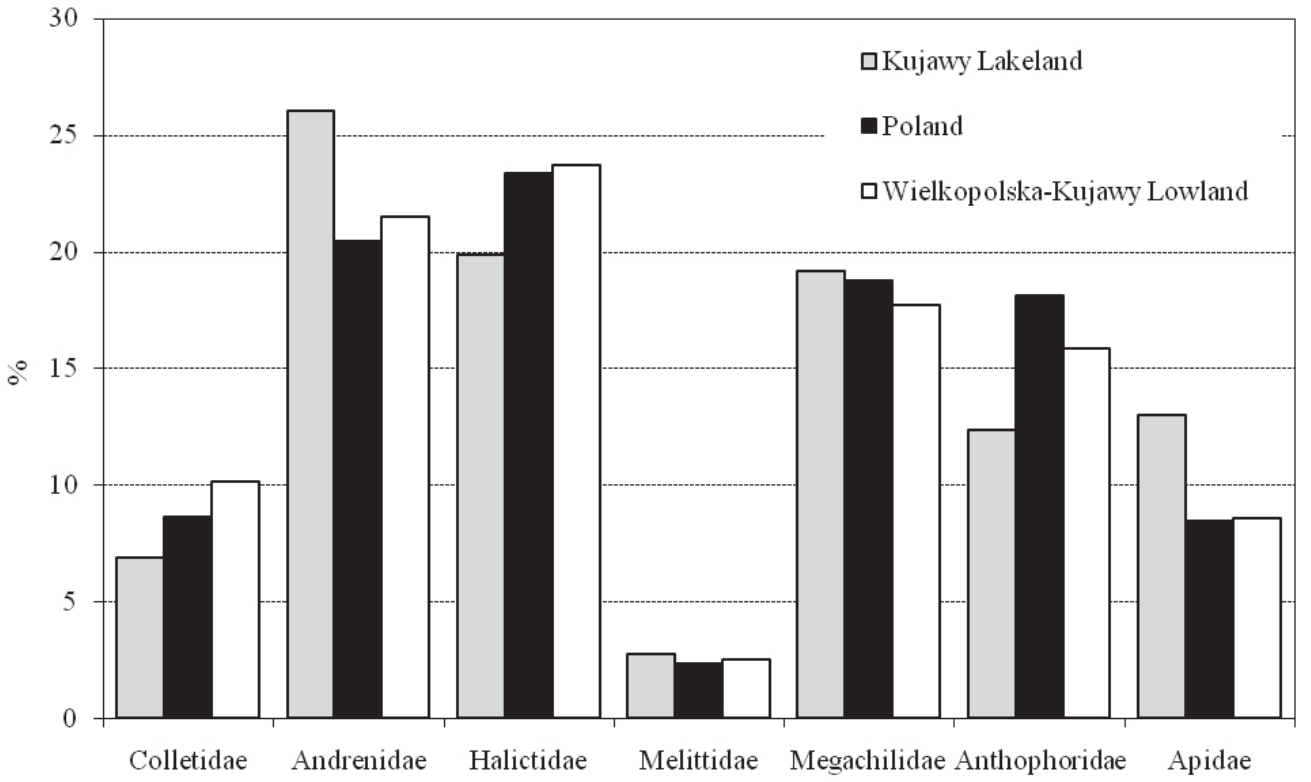

Fig. 5. Percentage contributions of individual families to the total number of wild bee species in the Kujawy Lakeland, as compared to the bee fauna of Poland and the Wielkopolska-Kujawy Lowland. 


\section{Species richness and seasonal dynamics of red clover by bumblebees}

Three-year observations (2011-2013) of bumblebees on two red clover fields provided data on 10 species. In field ' $a$ ', two more species were recorded than in field ' $b$ '. Considering the total numbers of individual bee species in the three years, in both fields eudominants included Bombus terrestris, B. lucorum, B. muscorum, B. lapidarius, and B. pascuorum.

Before the second moving of red clover, more bumblebees were recorded than before the first harvest. An exception is field ' $b$ ', where bumblebee density in 2011 was identical in both periods. The markedly lower density of bumblebees at this site than at the other sites was due to sporadic grazing of cattle in the field in 2011.

It is noteworthy that in 2011 and 2013 in these fields the number of bumblebee species before the second moving was higher than before the first harvest. In 2012, species richness was the same in both periods.

Species composition of bumblebees differed between years. Bombus muscorum was most abundant in field ' $a$ ' (before both harvests) and ' $b$ ' (before the first harvest) in 2011, and also in field 'a' (before the second moving) in 2013. In nearly all the other instances, before both harvests, the dominant species was $B$. terrestris, except before the second moving in field ' $\mathrm{b}$ ', where in 2011 B. pascuorum was the most frequent, and in 2013 B. sylvarum (Table 2).

Table 2. Abundance of bumblebees (Bombus spp.) in red clover fields in the Kujawy Lakeland.

\begin{tabular}{|c|c|c|c|c|c|c|c|c|c|c|c|c|}
\hline \multirow{5}{*}{ Species } & \multicolumn{12}{|c|}{ Clover } \\
\hline & $\mathrm{a}$ & $\mathrm{b}$ & $\mathrm{a}$ & $\mathrm{b}$ & $\mathrm{a}$ & $\mathrm{b}$ & $\mathrm{a}$ & $\mathrm{b}$ & $\mathrm{a}$ & $\mathrm{b}$ & $\mathrm{a}$ & $\mathrm{b}$ \\
\hline & \multicolumn{12}{|c|}{ Years and cuts } \\
\hline & \multicolumn{4}{|c|}{2011} & \multicolumn{4}{|c|}{2012} & \multicolumn{4}{|c|}{2013} \\
\hline & \multicolumn{2}{|c|}{ I } & \multicolumn{2}{|c|}{ II } & \multicolumn{2}{|c|}{ I } & \multicolumn{2}{|c|}{ II } & \multicolumn{2}{|c|}{ I } & \multicolumn{2}{|c|}{ II } \\
\hline Bombus hortorum & 12 & 2 & 8 & 1 & 7 & 10 & 18 & 17 & 8 & 2 & 7 & 23 \\
\hline Bombus humilis & & & 1 & & & & & & & & 1 & \\
\hline Bombus lapidarius & 7 & 1 & 3 & 1 & 18 & 33 & 40 & 51 & 12 & 7 & 17 & 27 \\
\hline Bombus lucorum & & & 1 & & 14 & 12 & 5 & 33 & & & 1 & 1 \\
\hline Bombus muscorum & 36 & 5 & 114 & 2 & 2 & 1 & 16 & 28 & 4 & 9 & 36 & 20 \\
\hline Bombus pascuorum & 9 & 4 & 29 & 6 & 3 & 5 & 19 & 25 & 9 & 6 & 33 & 30 \\
\hline Bombus ruderarius & 1 & & 3 & 2 & 6 & 9 & 13 & 16 & 13 & 20 & 10 & 7 \\
\hline Bombus sylvarum & 17 & 3 & 16 & 1 & 3 & 2 & 10 & 37 & 3 & 3 & 18 & 33 \\
\hline Bombus terrestris & 2 & & 10 & 2 & 38 & 64 & 71 & 113 & 17 & 31 & 15 & 15 \\
\hline Bombus veteranus & & & & & & & & & & & 1 & \\
\hline Number of individuals & 84 & 15 & 185 & 15 & 91 & 136 & 192 & 320 & 66 & 78 & 139 & 156 \\
\hline Number of species & 7 & 5 & 9 & 7 & 8 & 8 & 8 & 8 & 7 & 7 & 10 & 8 \\
\hline
\end{tabular}

\section{DISCUSSION AND CONCLUSIONS}

The results of this study in the Kujawy Lakeland supplement our knowledge of the bee fauna of the Wielkopolska-Kujawy Lowland. In the study area, 146 species of wild bees were recorded. They represent 29 genera, and 7 families, accounting for $30.7 \%$ of bee species reported from Poland so far (Banaszak 2004) and $46.2 \%$ of bee species known from the Wielkopolska-Kujawy Lowland (Banaszak 2010c). Incomplete list of bee species can be explained for example by missing of Andrena fulvida in spite of the recording of its cleptoparasite Nomada opaca. The relatively high environmental value of the investigated 
habitats is confirmed by the presence of red-listed species of wild bees, which in total account for about $10 \%$ of all the recorded species.

As compared to the fauna of Poland (Banaszak 2004) and of the Wielkopolska-Kujawy Lowland (Banaszak 2010c), in this study the percentage contributions of species of 2 bee families were the markedly higher: the Andrenidae and Apidae (Fig. 5). In contrast, lower contributions were recorded for the families Colletidae, Halictidae, and Anthophoridae, while the contributions of the families Megachilidae and Melittidae were very much like generally in Poland and in the Wielkopolska-Kujawy Lowland.

A particularly high species diversity of wild bees was observed in xerothermic grassland at the archaeological site in Mietlica, located within the Landscape Park. A comparable result was recorded in xerothermic grassland on the Budzyń Esker in the Wielkopolska National Park, where 69 bee species were found (Banaszak 1983). It is surprising that in both localities, although markedly different in area (grassland near Lake Gopło 0.2 ha and grassland near Lake Budzyńskie about 1.3 ha), nearly identical numbers of species were recorded. In comparison, in the proposed "Folusz" nature reserve near Szubin, 88 species were found in an area of 3.0 ha (Banaszak et al. 2004). In both "Folusz" and Mietlica, the eudominant was the notably oligolectic Andrena vaga, which collects pollen from flowers of Salix spp. (Bischoff et al. 2003, Vanderplanck et al. 2003), flowering on nearby meadows.

The high faunistic richness of xerothermic grassland probably results from the species richness of bee forage plants at that site. The dominance of Andrena vaga in the total catch and on xerothermic grassland results from its very numerous nesting there. Its colonies covered in total about $73.5 \mathrm{~m}^{2}$. To determine the dynamics of its population, as well as the sex ratio of the host and its parasite, bees were counted in a belt $3.5 \mathrm{~m}$ wide along $21.0 \mathrm{~m}$ of the embankment length (Table 3). The flight season of $A$. vaga lasted from mid-April till mid-June. It is noteworthy that males of this mining bee species emerged slightly earlier, which was not recorded because of unfavourable weather conditions. In the colony, females and males reached the highest numbers of 338 and 125, respectively. As the host numbers decreased, the numbers of their nest parasite, Nomada lathburiana, increased. The most frequent wild bees on xerothermic grassland included also Bombus terrestris and Anthophora plumipes. The former collected nectar and pollen from 6 plant species, while the latter was observed on Salvia pratensis, which flowered abundantly in May.

Table 3. Population dynamics of Andrena vaga and its cleptoparasite Nomada lathburiana, observed in an area of 73.5 $\mathrm{m}^{2}$ of xerothermic grassland in the "Nadgoplański Park Tysiąclecia" Landscape Park in 2015.

\begin{tabular}{|c|c|c|c|c|c|c|}
\hline \multirow{2}{*}{ Period } & \multirow{2}{*}{ Temperature $\left[{ }^{\circ} \mathrm{C}\right]$} & \multicolumn{3}{|c|}{ Andrena vaga } & \multicolumn{2}{|c|}{ Nomada lathburiana } \\
\hline & & 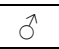 & q & Remarks & 0 & + \\
\hline $11 \mathrm{Apr}$ & 16.5 & 125 & 338 & copulation $+9+$ with pollen & 3 & \\
\hline $19 \mathrm{Apr}$ & 12 & 36 & - & copulation & 29 & 20 \\
\hline 23 May & 20 & - & 16 & part of $\not$ 우 with pollen & & 11 \\
\hline 20 Jun & 26 & 1 & - & - & - & - \\
\hline
\end{tabular}

The study site in Mietlica seems very interesting from the point of view of nature conservation, so it is necessary to undertake measures to remove successively the self-sown oaks at the foot of the slope. Another problem is the uncontrolled penetration of the slope by local inhabitants riding quads, which probably have a negative effect on nesting of e.g. the large local population of $A$. vaga.

On the synanthropic site, spring species prevailed: Osmia rufa, Andrena haemorrhoa, and Anthophora plumipes. Their high contribution was associated with rich food resources: 
flowering fruit trees Malus domestica and Prunus spp. as well as Taraxacum officinale in the herb layer. At this site, nests of Anthophora plumipes and Osmia rufa were found in a clay wall of a farm building. We observed also Melecta albifrons, which is a nest parasite of A. plumipes.

The periodically waterlogged meadow proved to be a perfect site for Macropis europaea, which clearly dominated there $(33.0 \%)$. It is a narrowly oligolectic bee species, adapted to waterlogged conditions. Its females collect pollen and oils for the offspring e.g. from Lysimachia vulgaris, which flourished in the meadow.

Sandy grassland was characterized by a high contribution of thermophilous bee species: Heriades crenulatus and Dasypoda altercator. Among bumblebees, the most abundant was Bombus lapidarius. The 3 species mentioned above visited flowers of Cenataurea stoebe and C. scabiosa. Sandy grassland b showed a different dominance structure of bees. The most frequent was Bombus lapidarius, followed by Halictus sexcinctus, and Heriades crenulatus. This can be explained by the fact that ecological succession is more advanced there than on sandy grassland a.

On the moderately moist meadow, the major species were Bombus lapidarius, B. pratorum, and Andrena pilipes. This site was visited twice in summer (31 Jul 2015 and 15 Aug 2015), and those species were observed on flowers of Centaurea jacea. Forest communities located in the vicinity were probably favourable sites for Bombus pratorum.

The extremely high density of Heriades crenulatus in comparison with ubiquitous $H$. truncorum requires comment. H. crenulatus is sub-Ponto-Mediterranean species, in Poland infrequent. In other countries of the Central Europe it is local species also and its density is higher only at not disturbed areas (Přidal \& Veselý 2011).

The major bumblebee species on red clover included Bombus terrestris, B. lucorum, B. muscorum, and B. lapidarius. Similar results were reported by Błażejewska et al. (1961), Ruszkowski \& Biliński (1968), Biliński (1977), Anasiewicz (1976), and Banaszak (1984). All these Bombus species are common in Poland. The small differences in dominance structure of bumblebees between the cited publications and this study depend on the types of habitats surrounding the red clover fields.

When comparing the numbers of bumblebee species before the first and second moving, we did not confirm the trend reported by Biliński (1977), who observed more Bombus spp. before the first harvest than before the second one. The seasonal dynamics of red clover pollination by bumblebees in individual years probably depended on weather, which was not analysed here.

\section{ACKNOWLEDGEMENTS}

We sincerely thank Jolanta Sobieraj and Michał Betliński for help in our field research.

\section{REFERENCES}

AlfKEN J. D. 1909. Beitrag zur Kenntnis der Apidenfauna von Westpreussen (Sammelbericht). Bericht des Westpreussischen, Botanisch-Zoologischen Vereins, Danzig 31: 101-123.

AlfKen J. D. 1912. Die Bienenfauna von Westpreussen. Bericht des Westpreussischen Botanisch-Zoologischen Vereins, Danzig 34: 1-96.

ANASIEWICZ A. 1976. Dzikie błonkówki pszczołowate (Apoidea, Hymenoptera) występujące w biocenozie kwitnącej koniczny czerwonej. Polskie Pismo Entomologiczne 46: 145-153.

BANASZAK J. 1982. Pszczoły (Apoidea, Hymenoptera) Niziny Wielkopolsko-Kujawskiej. Fragmenta Faunistica 27 (7): 75-92.

BANASZAK J. 1983. Ecology of bees (Apoidea) of agricultural landscape. Polish Ecological Studies 9 (4): $421-505$.

BANASZAK J. 1984. The occurrence and numbers of bees (Apoidea) on some cultivated crop plants in the Wielkopolska region (West Poland). Polskie Pismo Entomologiczne 53: 623-631.

BANASZAK J. 1987. Fauna pszczół (Hymenoptera, Apoidea) Niziny Wielkopolsko-Kujawskiej na przestrzeni pól wieku. Badania Fizjograficzne nad Polską Zachodnią, Ser. C 36: 67-77. 
Banaszak J. 2004. Apidae. In: Bogdanowicz W., Chudzicka E., Pilipiuk I. \& Skibińska E. (eds.). Fauna Polski. Charakterystyka i wykaz gatunków. Volume 1. Muzeum i Instytut Zoologii Polskiej Akademii Nauk, Warszawa, pp. 358-362.

BANASZAK J. 2006. Bees (Hymenoptera: Apiformes) in the Narew National Park. Polish Journal of Entomology 75: $511-537$.

BANASZAK J. 2010a. Bees of the Masurian Landscape Park: diversity and ecology (Hymenoptera: Apoidea, Apiformes). Polish Journal of Entomology 79 (1): 25-53.

BANASZAK J. 2010b. Bees of the Wolin National Park: diversity and ecology (Hymenoptera: Apoidea, Apiformes). Polish Journal of Entomology 79 (1): 55-76.

BANASZAK J. 2010c. The persistance of and changes in a bee fauna over the last century: case of WielkopolskaKujawy Lowland in western Poland (Hymenoptera: Apoidea, Apiformes). Polish Journal of Entomology 79 (4): $367-409$.

BANASZAK J., RATYŃSKA H. \& BANASZAK W. A. 2004. Proponowany rezerwat „Folusz” pod Szubinem jako ostoja termofilnej szaty roślinnej i fauny żądłówek (Hymenoptera: Aculeata: Apoidea, Scolioidea). Badania Fizjograficzne nad Polską Zachodnią, C, 50: 101-132.

BAnasZaK J. \& KowalczyK J. K. 2007. Notes on bees (Hymenoptera: Apoidea: Apiformes) of central Poland. Fragmenta Faunistica 50 (1): 1-18.

BANASZAK J. \& JAROSZEwICZ B. 2009. Bees of the Białowieża National Park and adjacent areas, NE Poland (Hymenoptera: Apidea, Apiformes). Polish Journal of Entomology 78 (2): 281-313.

BANASZAK J. \& TWERD L. 2015. Pszczoły rezerwatu leśnego „Dziki Ostrów” niedaleko Bydgoszczy. Chrońmy Przyrodę Ojczystą 71 (1): 53-60.

BILIŃSKI M. 1977. Oblot koniczyny czerwonej przez owady zapylające. Polskie Pismo Entomologiczne 47: $487-505$

BilińsKi M. \& RuszKowski A. 1991. Trzmiele Wielkopolski. Pszczelnicze Zeszyty Naukowe 35 (1): $127-138$.

BISCHOFF I., FELTGEN K. \& BRECKNER D. 2003. Foraging strategy and pollen preferences of Andrena vaga (PANZER) and Colletes cunicularius (L.) (Hymenoptera: Apidae). Journal of Hymenoptera Research 12: 220-237.

BŁAŻEJEWSKA A., LEJA S. \& MATYSIAK T. 1961. Z obserwacji nad występowaniem trzmieli (Bombus Latr.) na uprawach koniczyny czerwonej w okolicy Torunia. Zeszyty Naukowe Uniwersytetu Mikołaja Kopernika w Toruniu. Biologia. 8, 6: 51-60.

Celary W. 1999. New and rare species of the genus Hylaeus Fabricius, 1793 for the fauna of Poland (Hymenoptera: Apoidea: Colletidae). Acta zoologica cracoviensia 42 (2): 259-264.

CElARY W. \& WiŚniowsKi B. 2001. Contribution to bee fauna (Hymenoptera: Apoidea) of Poland. Acta zoologica cracoviensia 44 (4): 413-418.

CHAO A. 1987. Estimating the population size for capture-recapture data with unequal catchability. Biometrics 43: $783-791$.

COLWELL R.K. 2013. EstimateS: Statistical estimation of species richness and shared species from samples. Version 9. Available at http://purl.oclc.org/estimates (3 Jan 2016).

Dylewska M. 2000. Pszczołowate - Apidae. Podrodzina Andreninae. Błonkówki. Klucze do oznaczania owadów Polski 24, 68d. Polskie Towarzystwo Entomologiczne, Toruń, 152 pp.

DZIEDUSZYCKA B. 1985. Demographic and Economic Transformation in the Area Surrounding the Early Medieval Kruszwica. Archaeologia Polona 24: 73-103.

Gotelli N.J. \& COLWELL R.K. 2001. Quantifying biodiversity: procedures and pitfalls in measurement and comparison of species richness. Ecology Letters 4: 379-391.

HonCZARENKo J. 1965. Trzmiele (Bombus Latr.) zapylające koniczynę czerwoną (Trifolium pratense L.) w okolicach Szczecina. Szczecińskie Towarzystwo Naukowe, Wydział Nauk Przyrodniczo-Rolniczych 20 (1): 1-60.

KASPRZAK K. \& NIEDBAŁA W. 1981. Wskaźniki biocenotyczne stosowane przy porządkowaniu i analizie danych w badaniach ilościowych. In: GóRNY M. \& GRÜM L. (eds.). Metody stosowane w zoologii gleby, pp. $397-409$. Wydawnictwo Naukowe PWN, Warszawa.

KONDRACKi J. 2009. Geografia regionalna Polski. Wydawnictwo Naukowe PWN, Warszawa, 444 pp.

Kosior A. 1980. Rola trzmieli (Bombus Latr.) w biocenozach Bieszczadów Zachodnich. Ochrona Przyrody 43: 189-222.

KowALSKI M. 20.08.2009. Ludzkie szczątki poniewierają się w Piotrkowie Kujawskim. Gazeta Pomorska. Available at http:/www.pomorska.pl/pomorska24/art/7067627,ludzkie-szczatki-poniewieraja-sie-w-piotrkowie-kujawskimzdjecia,id,t.html (31 Jan 2016)

MAGURRAN A. E. 2004. Measuring biological diversity. Blackwell, 215 pp.

MAtUSZKIEWICZ J. M. 2008a. Regionalizacja geobotaniczna Polski. Instytut Geografii i Przestrzennego Zagospodarowania Polska Akademia Nauk, Warszawa. Available at http://www.igipz.pan.pl/Regionygeobotaniczne-zgik.html (31 Jan 2016)

MAtUsZKiewiCZ J. M. 2008b. Potencjalna roślinność naturalna Polski. Instytut Geografii i Przestrzennego Zagospodarowania Polska Akademia Nauk, Warszawa. Available at https:/www.igipz.pan.pl/Roslinnoscpotencjalna-zgik.html (31 Jan 2016) 
MiLESKA M. I. 1994. Pojezierze Kujawskie. [in:] Słownik geograficzno-krajoznawczy Polski. Wydawnictwo Naukowe PWN, 329 pp.

Nieto A., Roberts S. P. M., Kemp J., Rasmont P., Kuhlmann M., García CRiado M., Biesmeijer J. C., Bogusch P., Dathe H. H., De la Rúa P., De Meulemeester T., Dehon M., Dewulf A., OrTiz-SÁnchez F. J., Lhomme P., Pauly A., Potts S.G., Praz C., Quaranta M., Radchenko V.G., Scheuchl E., Smit J., Straka J., Terzo M., TomoziI B., Window J. \& Michez D. 2014. European Red List of Bees. Publication Office of the European Union, Luxembourg, p. 84. Available at http://bookshop.europa.eu/is-bin/INTERSHOP.enfinity/WFS/EUBookshop-Site/en_GB/-/EUR/ViewPublication-Start?PublicationKey=KH0714078 (29 Aug 2016).

PAWLIKOWSKI T. 1989a. Struktura zgrupowań dzikich pszczołowatych (Hymenoptera, Apoidea) z obszarów rolnych o różnych typach parcelacji powierzchni uprawnej. Acta Universitatis Nicolai Copernici. Biologia. 33, 70: 31-46.

PAWLIKOWSKI T. 1989b. Struktura zgrupowań dzikich pszczołowatych (Hymenoptera, Apoidea) z siedlisk ekotonowych „,pole-bór sosnowy”. Acta Universitatis Nicolai Copernici. Biologia. 33, 70: 101-109.

PAWLIKOWSKI T. 1992a. Fenologia trzmieli (Apoidea, Bombus Latr.) w Kotlinie Toruńskiej. Acta Universitatis Nicolai Copernici. Biologia. 39, 78: 63-75.

PAWLIKOWSKI T. 1992b. Struktura zespołów pszczołowatych (Hymenoptera, Apoidea) na obszarach leśnych Kotliny Toruńskiej. Rozprawy, Uniwersytet Mikołaja Kopernika, Toruń, 115 pp.

PAWLIKOWSKI T. 1993. Zadrzewienia śródpolne jako korytarze ekologiczne rozprzestrzeniania sie trzmieli (Apoidea, Bombus Latr.) w krajobrazie rolniczym. Acta Universitatis Nicolai Copernici. Biologia. 43, 84: 17-29.

PŘIDAL A., VeSElÝ P. 2011. Changes in the composition of the bee populations of the Mohelno Serpentine Steppe after 70 years (Hymenoptera: Apiformes). Acta Universitatis Agriculturae et Silviculturae Mendelianae Brunensis 59 (6): 291-311. Available at http://acta.mendelu.cz/media/pdf/actaun_2011059060291.pdf (29 Aug 2016)

Ruszkowski A. \& BILIŃSKi M. 1968. Oblot koniczyny czerwonej przez trzmiele. Pamiętnik Puławski - prace Instytutu Uprawy Nawożenia i Gleboznawstwa 31: 202-220.

SOWA S., RUSZKOWSKI A., BILIŃSKI M. \& KosIOR A. 1974. Liczebność i skład gatunkowy owadów zapylających koniczynę czerwoną w niektórych rejonach Polski w 1972 i 1973 r. [in:] Wstępne wyniki badań nad nasiennictwem koniczyny czerwonej. Instytut Uprawy Nawożenia i Gleboznawstwa, Puławy 100: 17-19.

Sowa S., RUSzKowsKi A., BILIŃSKI M. \& Kosior A. 1983. Liczebność i skład gatunkowy owadów zapylających koniczynę czerwoną (Trifolium pratense L.) w Polsce w latach 1972-1975. Biuletyn Instytutu Hodowli i Aklimatyzacji Roślin 151: 147-162.

Sowa S., DYLewSKa M., BiLiŃSKI M. \& RusZKowSKi A. 1991a. Trzmiele bydgoskiego, pilskiego, toruńskiego i włocławskiego. Pszczelnicze Zeszyty Naukowe 35 (1): 113-125.

Sowa S., DYLEWSKA M. \& RuSzKOWSKi A. 1991b. Trzmiele Pojezierza Mazurskiego. Pszczelnicze Zeszyty Naukowe 35 (1): 103-111.

StRAKa J. \& Bogush P. 2007. Description of immature stages of cleptoparasitic bees Epeoloides coecutiens and Leiopodus trochantericus (Hymenoptera: Apidae: Osirini, Protepeolini) with remarks to their unusual biology. Entomologica Fennica 18: 242-254. Available at http://aculeataresearch.com/attachments/article/56/24-eplarvy.pdf (31 Jan 2016).

SzUlCZEWSKI J.W. 1948. Błonkówki (Hymenoptera) Wielkopolskiego Parku Narodowego. Cz. III: Pszczołowate (Apidae). Prace monograficzne nad Przyrodą Wielkopolskiego Parku Narodowego pod Poznaniem 2 (3): 71-90.

TORKA V. 1913. Die Bienen der Provinz Posen. Zeitschrift für Naturwissenschaften, Abt. 20: 97-181.

TORKA V. 1933. Nachtrage zu meiner Veröffentlichung über "Die Bienen der Provinz Posen". Deutsche Wissenschaftliche Zeitschrift für Polen 26: 83-94.

VANDERPLANCK P. M., BRUNEAU E. \& Michez D. 2009. Oligolectisme et décalage phénologique entre plante hôte et pollinisateur: étude de deux espèces printanières psammophiles, Colletes cunicularius (L.) (Hymenoptera, Colletidae) et Andrena vaga (Panzer) (Hymenoptera, Andrenidae). Osmia 3: 23-27. Available at http://www.zoologie.umh.ac.be/hymenoptera/biblio/237_Vanderplank_et_al._2009_palynologie.pdf (31 Jan 2016)

WiLliams N. M, MinCKLEY R. L. \& SilveIRA F. A. 2001. Variation in native bee faunas and its implications for detecting community changes. Conservation Ecology 5 (1): 7. Available at http://www.consecol.org/vol5/iss 1/art7/ (31 Jan 2016)

Woś A. 1999. Klimat Polski. Wydawnictwo Naukowe PWN, Warszawa, 301 pp.

WoŚ. A. 2003. Klimat regionu środkowowielkopolskiego w świetle częstości występowania wybranych typów pogody i ich zmienności w latach 1951-2000. [in:] BANASZAK J. (ed.). Stepowienie Wielkopolski pól wieku później. Wydawnictwo Akademii Bydgoskiej im. Kazimierza Wielkiego, Bydgoszcz, pp. 27-42.

Zarządzenie Regionalnego Dyrektora Ochrony Środowiska w Bydgoszczy i Regionalnego Dyrektora Ochrony Środowiska w Poznaniu z dnia 23 września 2015 r. zmieniające zarządzenie w sprawie ustanowienia planu zadań ochronnych dla obszaru Natura 2000 Jezioro Gopło PLH040007. Poz. 5673. Available at http://g.ekspert.infor.pl/p/_dane/akty_pdf/_U84/2015/185/5673.pdf\#zoom=90 (31 Jan 2016). 


\section{STRESZCZENIE}

\section{[Pszczoly (Hymenoptera: Apoidea, Apiformes) Pojezierze Kujawskie (centralna Polska)]}

Praca wypełnia lukę w poznaniu fauny pszczół Apoidea Niziny Wielkopolsko-Kujawskiej, uzupełniając dane dotyczące obszaru Pojezierza Kujawskiego. Przedstawiono wyniki badań prowadzonych na 14 stanowiskach tego mezoregionu. Wykazano 146 gatunków dziko żyjących pszczół, co stanowi 30,7\% pszczół wymienionych dotychczas z naszego kraju i 46,2\% gatunków znanych z Niziny Wielkopolsko-Kujawskiej.

W zgrupowaniu odławianych i zaobserwowanych pszczół Pojezierza Kujawskiego wyraźnym eudominantem okazał się Bombus terrestris (14,6\%). Dominantami były natomiast następujące taksony: Andrena vaga (8.4\%), Bombus lapidarius (7,4\%), Andrena haemorrhoa (6,5\%), Bombus pascuorum $(6,0 \%)$ i Osmia rufa $(5,4 \%)$.

W omawianym materiale 14 gatunków to taksony zagrożone. Wśród nich znalazły się: Andrena alfkenella, A. falsifica, A. nasuta, A. nycthemera, A. potentillae, A. suerinensis, Anthocopa bidentata, A. papaveris, Epeoloides coecutiens, Hylaeus bisinuatus, H. gracilicornis, H. gredleri, Nomada moeschleri oraz N. opaca.

Środowiskiem wyróżniającym się pod względem różnorodności gatunkowej dzikich pszczół okazała się murawa kserotermiczna na obszarze grodziska w Mietlicy, która leży w granicach Parku Krajobrazowego Nadgoplański Park Tysiąclecia.

Trzyletnie obserwacje nad występowaniem gatunków trzmieli na dwóch uprawach koniczyny czerwonej dały ogółem informacje o 10 gatunkach. Głównymi przedstawicielami trzmieli na koniczynie czerwonej były: Bombus terrestris i B. lucorum, B. muscorum oraz B. lapidarius. 